\title{
Deteksi Bakteri Pencemar Lingkungan (Coliform) Pada Ikan Sapu-Sapu Asal Sungai Ciliwung
}

\author{
Riris Lindiawati Puspitasari ${ }^{1}$, Dewi Elfidasari ${ }^{2}$, Yorianta Sasaerila Hidayat ${ }^{3}$, Fatihah Dinul \\ Qoyyimah $^{4}$, Fatkhurokhim ${ }^{5}$ \\ 1, 2, 3, 4,5 Program Studi Biologi, Fakultas Sains dan Teknologi, Universitas Al Azhar Indonesia. \\ Komplek Masjid Agung Al Azhar, Jl. Sisingamangaraja, Kebayoran Baru, Jakarta 12110
}

Penulis untuk Korespondensi/E-mail: riris.lindiawati@uai.ac.id

\begin{abstract}
Abstrak - Sungai Ciliwung merupakan salah satu sumber kehidupan bagi masyarakat. Berdasarkan survey yang dilakukan, ikan sapu-sapu sungai Ciliwung juga dimanfaatkan sebagai pangan oleh masyarakat. Penelitian ini bertujuan untuk mendeteksi keberadaan bakteri Coliform dan mikroorganisme yang terdapat pada ikan sapu-sapu asal perairan sungai Ciliwung. Deteksi Coliform dilakukan dengan metode uji praduga dan uji konfirmasi terhadap insang, usus, daging serta kulit abdomen ikan sapu-sapu. Uji praduga dengan menggunakan media Lactose Broth (LB), sedangkan uji konfirmasi dengan media Brilliant Lactose Broth (BGLB). Hasil MPN dilihat dari tabel yang memberikan nilai duga terdekat dengan kombinasi tabung positif dan tabung negatif pada uji konfirmasi. Hasil yang didapat menunjukan seluruh sampel memiliki nilai MPN melebihi batas maksimum Coliform pada makanan. Jadi daging, insang, kulit abdomen, dan usus pada ikan sapu-sapu tidak layak untuk dikonsumsi oleh masyarakat.
\end{abstract}

Kata Kunci - Coliform, ikan sapu-sapu, sungai Ciliwung

Abstract - Ciliwung River is one of life source for society. Based on the survey conducted, Ciliwung river broom fish is also used as food by the community. This study aims to detect the presence of Coliform bacteria and microorganisms found in broom fish from the Ciliwung River waters. Coliform detection was performed by presumptive test method and confirmation test on gills, intestines, meat and abdominal skin of sweeper fish. Prediction test using Lactose Broth (LB) media, while confirmation test with Brilliant Lactose Broth (BGLB) media. MPN results are seen from the table that gives the closest possible value to the positive tube and negative tube combination in the confirmation test. The results show that all samples have MPN values exceeding the maximum limit of Coliform in foods. So the meat, the gills, the abdominal skin, and the intestines in the broom fish are not fit for consumption by the public.

Keywords - Coliform, Cattle Fish, River Cilliwung

\section{PENDAHULUAN}

nalisa adanya pencemaran limbah
domestik dalam suatu lingkungan
merupakan hal penting untuk dilakukan
berkaitan dengan kesehatan, keindahan dan
alasan ekologi lainnya. Pencemaran domestik
yang umumnya berasal dari limbah manusia
dan hewan merupakan faktor penyebab utama
menurunnya kualitas air. Salah satu parameter
yang biasa digunakan untuk mengidentifikasi
adanya kontaminasi limbah domestik pada suatu kawasan adalah karakteristik biologi berupa keberadaan bakteri Coliform.

Bakteri Coliform merupakan mikroorganisme yang menjadi indikator adanya pencemaran lingkungan atau sanitasi yang kurang baik akibat limbah domestik. Bakteri Coliform tergolong dalam famili Enterobacteriaceae yang dibedakan ke dalam 2 kelompok, yaitu kelompok fekal dan non fekal. Coliform fekal merupakan bakteri indikator yang menjadi tanda ada tidaknya pencemaran bakteri 
patogen. Ini disebabkan karena keberadaan koloni Coliform fekal berkolerasi positif dengan keberadaan bakteri patogen. Semakin sedikit kandungan Coliform menunjukan semakin baik kualitas air pada suatu kawasan.

Salah satu kawasan perairan di Jakarta yang mengalami pencemaran limbah domestik adalah sungai Ciliwung. Hasil penelitian kualitas perairan sungai Ciliwung berdasarkan keberadaan bakteri Coliform yang dilakukan pada tahun 2016 dengan menggunakan metode Most Probably Number (MPN) menunjukkan nilai MPN yang sangat tinggi, yaitu $>1100$ MPN/100 ml [1]. Hasil ini memberikan informasi bahwa perairan sungai Ciliwung sudah sangat tercemar oleh limbah domestik manusia. Pencemaran yang tinggi di Sungai Ciliwung berdampak langsung pada organisme yang hidup di sungai serta ekosistem Sungai Ciliwung, salah satunya adalah ikan sapu-sapu.

Ikan sapu-sapu merupakan ikan invasif dan memiliki kemampun bertahan hidup pada lingkungan yang sangat tercemar seperti sungai Ciliwung. Ikan ini disebut sapu-sapu karena memakan sisa-sisa pakan, alga, lumut, dan sisasisa biota mati yang berada di dasar perairan, termasuk limbah yang berada di kawasan perairan tersebut. Bagi sebagian besar masyarakat di sekitar Daerah Aliran Sungai (DAS) Ciliwung, ikan sapu-sapu dimanfaatkan sebagai sumber makanan. Salah satu bentuk olahan makanan dengan bahan baku ikan sapusapu adalah abon, siomay, bakso ikan dan otakotak [2] [3].

Adanya hasil penelitian yang menjelaskan tingginya nilai MPN bakteri Coliform di perairan sungai Ciliwung memberikan dugaan bahwa ikan sapu-sapu di kawasan tersebut kemungkinan besar juga mengandung bakteri tersebut. Akan tetapi hingga saat ini belum ada data atau hasil penelitian yang memberikan informasi kandungan bakteri Coliform maupun mikroorganisme lain pada ikan-sapu-sapu di sungai Ciliwung. Penelitian ini bertujuan untuk mendeteksi keberadaan bakteri Coliform dan mikroorganisme yang terdapat pada ikan sapusapu asal perairan sungai Ciliwung.

\section{METODE PENELITIAN}

Penelitian dilakukan selama 10 bulan, mulai dari bulan Oktober 2016 - Juli 2017. Pengambilan sampel ikan sapu-sapu dilakukan di sungai Ciliwung. Analisa keberadaan bakteri Coliform pada ikan sapusapu dilakukan di Lab. Mikrobiologi Universitas Al Azhar Indonesia, Jl. Sisingamangaraja, Komplek Masjid Agung, Jakarta Selatan.

Alat yang digunakan pada penelitian ini adalah wadah container (tempat membawa sampel ikan dari lapangan), laminar air flow, autoklaf, neraca analitik, mikroskop, inkubator, botol sampel, tabung biak, gelas piala, oven, tabung durham, gelas ukur, erlenmeyer, pipet, ose, sendok, botol steril, $\mathrm{pH}$ meter, bunsen, oven, kulkas, kamera digital, dan alat tulis menulis, tali, tisu, kapas, sarung tangan, masker, kertas label, aluminium foil.

Bahan-bahan yang digunakan antara lain media nutrient agar, akuades, glukosa. media Lactose Broth (LB), media Brilliant Green Lactose Broth (BGLB), Tripticase Soy Broth (TSB), Kasein, $\mathrm{NaCl}$ fisiologis $(0,85 \%)$, alkohol $70 \%$, dan akuades steril. Penelitian dilakukan dengan uji praduga dan uji konfirmasi. Nilai MPN dilihat dari tabel MPN 3 seri.

\section{HASIL DAN PEMBAHASAN}

Keberadaan bakteri Coliform pada lingkungan perairan dapat berasal dari limbah manusia (feses) yang dibuang ke kawasan perairan tersebut [4]. Infeksi Coliform pada manusia dapat disebabkan oleh konsumsi makanan produk hewan yang tercemar, misalnya daging dan susu [5]. Pemeriksaan bakteri Coliform pada ikan sapu-sapu menggunakan metode MPN, yaitu melalui uji praduga (presumptive test) dan uji konfirmasi atau penegasan (confirmative test). Uji penduga dilakukan dengan menggnakan media LB dan diinkubasi selama 48 jam. Hasil yang didapat pada uji praduga menunjukan bahwa seluruh sampel positif mengandung Coliform (Tabel 1). Sampel yang positif mengandung Coliform dilanjutkan pada uji konfirmasi dengan media BGLB. 
Tabel 1. Data hasil uji praduga pada ikan sapu-sapu Ciliwung dengan media LB

\begin{tabular}{ccccc}
\hline \multirow{2}{*}{$\begin{array}{c}\text { Ikan } \\
\text { ke- }\end{array}$} & Sampel & \multicolumn{3}{c}{ Jumlah Tabung Positif } \\
\cline { 3 - 5 } & Insang & 3 & $30^{-1}$ & $10^{-3}$ \\
\hline \multirow{3}{*}{1} & Daging & 3 & 3 & 3 \\
& Usus & 3 & 3 & 3 \\
& Kulit abdomen & 3 & 2 & 3 \\
& Insang & 3 & 3 & 3 \\
2 & Daging & 3 & 2 & 3 \\
& Usus & 3 & 3 & 3 \\
& Kulit abdomen & 3 & 3 & 3 \\
\hline
\end{tabular}

Uji konfirmasi dilakukan untuk mengetahui nilai MPN pada seluruh sampel. Nilai MPN ditentukan dengan melihat jumlah tabung positif setelah diinkubasi dan hasil dilihat dari tabel MPN Coliform. Hasil yang didapat pada sampel ke-1 insang memiliki nilai MPN 150, daging 93, usus 1100, dan kulit abdomen 290. Hasil sampel ke-2 menunjukan angka yang berbeda namun tidak berbeda nyata. Insang pada sampel ke-2 memiliki nilai MPN sebesar
210 , daging 43 , usus $>1100$, dan kulit abdomen 240 (Tabel 2).

Tabel 2 memperlihatkan bahwa usus merupakan bagian pada ikan sapu-sapu yang memiliki nilai MPN paling besar, setelah itu kulit abdomen, insang, dan daging. Penelitian terhadap cemaran air Ciliwung menunjukan nilai MPN melebihi batas maksimal syarat air minum, yaitu >1100[1].

Tabel 2. Data hasil uji konfirmasi pada ikan sapu-sapu sungai Ciliwung dengan media BGLB

\begin{tabular}{|c|c|c|c|c|c|}
\hline \multirow{2}{*}{$\begin{array}{l}\text { Ikan } \\
\text { ke- }\end{array}$} & \multirow{2}{*}{ Sampel } & \multicolumn{3}{|c|}{ Jumlah Tabung Positif } & \multirow{2}{*}{$\mathrm{MPN} / \mathrm{g}$} \\
\hline & & $10^{-1}$ & $10^{-2}$ & $10^{-3}$ & \\
\hline \multirow{4}{*}{1} & Insang & 3 & 2 & 1 & 150 \\
\hline & Daging & 3 & 2 & 0 & 93 \\
\hline & Usus & 3 & 3 & 2 & 1100 \\
\hline & Kulit abdomen & 3 & 2 & 3 & 290 \\
\hline \multirow{4}{*}{2} & Insang & 3 & 2 & 2 & 210 \\
\hline & Daging & 3 & 1 & 0 & 43 \\
\hline & Usus & 3 & 3 & 3 & $>1100$ \\
\hline & Kulit abdomen & 3 & 3 & 0 & 240 \\
\hline
\end{tabular}

Hasil tabel diatas (Tabel 2) menunjukkan bahwa dari semua sampel ikan sapu-sapu yang diuji tidak memenuhi syarat batas maksimal total bakteri Coliform. Berdasarkan Badan Standarisasi Nasional dan SNI-7388-2009 mengatakan bahwa batas maksimum nilai MPN Coliform $=10$ Coliform/gram. Hal ini menunjukan bahwa usus, daging, insang, dan kulit abdomen pada ikan sapu-sapu tidak layak untuk dikonsumsi oleh masyarakat.

\section{KESIMPULAN}

Nilai MPN beberapa bagian pada ikan sapusapu adalah sampel ke-1 insang memiliki nilai MPN 150, daging 93, usus 1100, dan kulit abdomen 290. Hasil sampel ke-2 menunjukan angka yang berbeda namun tidak berbeda nyata. Insang pada sampel ke-2 memiliki nilai MPN sebesar 210, daging 43, usus $>1100$, dan kulit abdomen 240. Jadi sampel usus, daging, insang, dan kulit abdomen tidak layak untuk dikonsumsi karena melebihi batas maksimum nilai MPN Coliform.

\section{DAFTAR PUSTAKA}

[1] R. Aulunia, "Studi kualitas air sungai Ciliwung berdasarkan faktor fisik dan kimia serta bakteri indikator pencemaran (Coliform) di kawasan Rindam Jaya Jakarta," Universitas Al Azhar Indonesia, Jakarta, 2016. 
[2] H. RK, "Diversitas Dan Hilangnya Jenisjenis Ikan Di Sungai Ciliwung dan Sungai Cisadane.," Berita Biologi, vol. 4, no. 10, pp. 491-501, 2011.

[3] N. A. Ratmini, "Kandungan logam berat Timbal $(\mathrm{Pb})$, Merkuri $(\mathrm{Hg})$ dan Cadmium (Cd) pada daging ikan sapu-sapu (Hyposarcus pardalis) di Sungai Ciliwung Stasiun Srengseng, Condet dan Manggarai," Vis Vitalis, vol. 2, no. 1, pp. 1-7, 2009.
[4] Feliatra, "Sebaran bakteri Escherichia coli di perairan Muara Sungai Bantan Bengkalis Riau," Universitas Riau, Pekan Baru, 2001.

[5] B. L. Balia, Harlia and D. Suryanto, "Jumlah baktri toal dan koliform pada sisi segar peternakan sapi perah rakyat dan susu pasteurisasi tanpa kemasan di pedagang kaki lima," in Prospek industri sapi perah menuju perdagangan bebas 2030, Bogor, 2008. 